\title{
PENGARUH SUBSTITUSI TEPUNG TERIGU DENGAN TEPUNG TEMPE DAN TEPUNG UBI JALAR KUNING TERHADAP KADAR PROTEIN, KADAR B-KAROTEN, DAN MUTU ORGANOLEPTIK ROTI MANIS
}

\author{
Kurniawati, Fitriyono Ayustaningwarno ${ }^{*}$ \\ Program Studi Ilmu Gizi Fakultas Kedokteran Universitas Diponegoro \\ Jl.Dr.Sutomo No.14, Semarang, Telp (024) 8453708, Email : gizifk@undip.ac.id
}

\begin{abstract}
Background: Increased of high protein and $\beta$-carotene food consumption is expected may prevent PEM and VAD. Tempeh is a high-protein food stuff, while orange-fleshed sweet potato had high $\beta$-carotene content. Sweet bread with substitution of tempeh and orange-fleshed sweet potato flours is expected could be an alternative food which had high protein and $\beta$-carotene content.

Objective: Analyze the effect of tempeh and orange-fleshed sweet potato flour substitution on protein and $\beta$-carotene content, and organoleptic quality of sweet bread.

Method: An one factor completely randomized experimental study used 5 level of tempeh and orange-fleshed sweet potato flour substitution, which were 0\%:0\%, 0\%:25\%, 10\%:15\%, 15\%:10\%, and 25\%:0\%. Statistical analysis of protein and $\beta$-carotene content used One Way ANOVA followed by Tukey and Duncan test, while analysis of organoleptic quality used Friedman and Wilcoxon test.

Result: Sweet bread with 25\% tempeh flour substitution had the highest protein content (14.38\%) and 25\% orangefleshed sweet potato flour substitution had the highest $\beta$-carotene content $(0.24 \mathrm{mg} / 100 \mathrm{~g})$. Substitution of $25 \%$ orange-fleshed sweet potato flour and substitution of 10\% tempeh $-15 \%$ orange-fleshed sweet potato flour had significant effect on $\beta$-carotene content. Tempeh and orange-fleshed sweet potato flour substitution also had significant effect on color, aroma, texture, and taste of sweet bread, but had no but had no significant effect on its protein content.

Conclusion: Tempeh flour substitution increased protein content in sweet bread and orange-fleshed sweet potato flour increased its $\beta$-carotene content. Sweet bread with $10 \%$ tempeh-15\% orange-fleshed sweet potato flour substitution were recommended.
\end{abstract}

Keywords: sweet bread; tempeh flour; sweet potato flour; protein; $\beta$-carotene

\begin{abstract}
ABSTRAK
Latar Belakang: Peningkatan konsumsi pangan kaya protein dan $\beta$-karoten diharapkan dapat mencegah KEP dan KVA. Tempe merupakan bahan pangan kaya protein, sedangkan ubi jalar kuning kaya akan kandungan $\beta$-karoten. Roti manis yang disubstitusi dengan tepung tempe dan tepung ubi jalar kuning diharapkan dapat menjadi produk pangan alternatif yang kaya kandungan protein dan $\beta$-karoten.

Tujuan: Menganalisis pengaruh substitusi tepung tempe dan tepung ubi jalar kuning terhadap kadar protein, $\beta$ karoten, dan mutu organoleptik roti manis.

Metode: Merupakan penelitian eksperimental rancangan acak lengkap satu faktor dengan 5 taraf perlakuan substitusi tepung tempe dan tepung ubi jalar kuning yaitu 0\%:0\%, 0\%:25\%, 10\%:15\%, 15\%:10\%, dan $25 \%: 0 \%$. Analisis statistik kadar protein dan $\beta$-karoten menggunakan uji One Way ANOVA serta uji Tukey dan Duncan, sedangkan analisis mutu organoleptik menggunakan uji Friedman dan Wilcoxon.

Hasil: Kadar protein tertinggi terdapat pada roti manis substitusi $25 \%$ tepung tempe $(14,38 \%)$ dan kadar $\beta$-karoten tertinggi terdapat pada roti manis substitusi $25 \%$ tepung ubi jalar kuning (0,24 mg/lo0g). Substitusi tepung ubi jalar kuning 25\% dan substitusi tepung tempe 10\%-tepung ubi jalar kuning $15 \%$ berpengaruh nyata terhadap kadar $\beta$-karoten roti manis. Substitusi tepung tempe dan tepung ubi jalar kuning juga berpengaruh nyata terhadap warna, aroma, tekstur, dan rasa roti manis, tetapi tidak berpengaruh nyata terhadap kadar proteinnya.

Kesimpulan: Substitusi tepung tempe meningkatkan kadar protein roti manis dan tepung ubi jalar kuning meningkatkan kadar $\beta$-karotennya. Roti manis yang direkomendasikan yaitu roti manis substitusi $10 \%$ tepung tempe-15\% tepung ubi jalar kuning.
\end{abstract}

Kata Kunci: roti manis; tepung tempe; tepung ubi jalar; protein; $\beta$-karoten

\section{PENDAHULUAN}

Kurang energi protein (KEP) merupakan salah satu masalah gizi utama di Indonesia yang dapat menyebabkan gangguan pertumbuhan fisik pada anak. ${ }^{1}$ Hasil Riskesdas tahun 2010 menunjukkan prevalensi anak usia 6-12 tahun yang

\footnotetext{
${ }^{*}$ Penulis Penanggungjawab
} 
bertubuh pendek dan kurus sebesar 35,6\% dan $12,2 \%$. Meskipun prevalensi nasional tersebut mengalami penurunan dibandingkan pada tahun 2007, tetapi masih terdapat 20 provinsi yang memiliki prevalensi anak pendek dan kurus di atas prevalensi nasional. $^{2}$ Di samping mengalami gangguan pertumbuhan, KEP pada anak juga seringkali dikaitkan dengan kejadian kurang vitamin A (KVA). ${ }^{3}$ Prevalensi kurang vitamin A (KVA) di Asia tenggara sebesar 24,3\% dan 85 juta di antaranya diderita oleh anak sekolah. Sementara itu, di Indonesia terdapat 12,6 juta kasus kurang vitamin A pada anak. ${ }^{4}$

Kurang energi protein dan kurang vitamin A dapat saling berkaitan. Pada anak KEP, adanya KVA dapat terjadi karena kurangnya asupan vitamin A, serta terhambatnya absorpsi, transportasi, dan pengkonversian vitamin A. Defisiensi protein dan seng pada anak KEP dapat mengurangi sistesis retinol binding protein (RBP), protein yang berfungsi mengangkut vitamin A. Sementara itu, adanya KVA dapat memperburuk keadaan KEP yang telah ada karena dapat mengurangi sistem kekebalan tubuh anak, sehingga anak lebih rentan mengalami penyakit infeksi. ${ }^{5,6}$ Penelitian pada anak usia sekolah di India menunjukkan bahwa KVA ditemukan berdampingan dengan KEP, dimana prevalensi anak KEP yang memiliki kadar retinol serum < $0,70 \mu \mathrm{mol} / \mathrm{L}$, sebesar $69,3 \%{ }^{4}$

Penyebab utama dari KEP adalah kurangnya asupan energi dan protein. Hasil Riskesdas tahun 2010 menunjukkan sebanyak 44,4\% anak usia 6-12 tahun mengonsumsi energi di bawah kebutuhan minimal $(<70 \%$ dari AKG bagi orang Indonesia), dan $30,6 \%$ mengonsumsi protein di bawah kebutuhan minimal pula $(<80 \%$ dari AKG bagi orang Indonesia). ${ }^{2}$ Upaya perbaikan gizi masyarakat dapat dilakukan dengan mendorong peningkatan konsumsi pangan melalui pendekatan penganekaragaman pangan. ${ }^{7}$ Untuk mencegah KEP dan KVA dapat dilakukan dengan meningkatkan konsumsi pangan tinggi protein dan vitamin A.

Tempe merupakan bahan pangan lokal sumber protein. Di dalam $100 \mathrm{~g}$ tempe terkandung $20,8 \mathrm{~g}$ protein yang kaya akan asam amino lisin $(43,1 \mathrm{mg} / \mathrm{g})$, yang dapat bersifat komplementer bila dipadukan dengan serealia yang minim kandungan lisin. Tempe juga memiliki protein dengan nilai cerna yang lebih tinggi, yaitu $83 \%$ bila dibandingkan dengan kedelai yang hanya $75 \% .{ }^{8}$ Sementara itu, ubi jalar kuning merupakan umbiumbian yang kaya $\beta$-karoten. Di dalam $100 \mathrm{~g}$ umbi segarnya terkandung $2.900 \mu \mathrm{g} \beta$-karoten. Produksi ubi jalar kuning di Indonesia melimpah, sekitar 1.886 ton per tahun, tetapi tingkat konsumsinya masih tergolong rendah, sekitar 1,4-17,8\% hampir di seluruh provinsi Indonesia. Optimalisasi konsumsi ubi jalar kuning dapat dilakukan dengan mengolahnya menjadi bentuk yang dapat diterima dan praktis, yaitu dengan penepungan. ${ }^{9}$

Program penganekaragaman pangan guna memperbaiki asupan gizi masyarakat dari makanan dapat berkembang dengan baik apabila memanfaatkan potensi bahan pangan lokal yang ada. Tempe dan ubi jalar kuning dalam bentuk tepung dapat digunakan dalam banyak aplikasi produk pangan seperti makanan ringan, biskuit, nugget, dan roti. Produk pangan yang dapat dikembangkan salah satunya adalah roti manis. Hasil Survei Sosial Ekonomi Nasional (Susenas) 2008 menunjukkan tingkat konsumsi roti manis yang meningkat dari tahun ke tahun. Sebanyak > $50 \%$ rumah tangga di perkotaan dan $>47 \%$ rumah tangga di pedesaan mengonsumsi roti manis $>20$ g/kapita/hari. ${ }^{10}$

Berdasarkan latar belakang tersebut maka dilakukan penelitian mengenai analisis kadar protein, kadar $\beta$-karoten, dan mutu organoleptik roti manis dengan substitusi tepung tempe dan tepung ubi jalar kuning untuk menghasilkan roti manis yang kaya protein dan $\beta$-karoten.

\section{METODE}

Penelitian yang dilakukan termasuk dalam bidang Ilmu Food Production. Penelitian ini dilaksanakan pada bulan Mei hingga Juni 2012 di Laboratorium Universitas Muhammadiyah Semarang dan Laboratorium Ilmu Pangan Universitas Katolik Soegijapranata Semarang. Penelitian ini merupakan penelitian eksperimental satu faktor dengan 5 taraf perlakuan.

Setiap perlakuan dan pengujian organoleptik pada penelitian ini dilakukan sebanyak 3 kali pengulangan. Taraf perlakuan dalam penelitian ini dapat dilihat pada Tabel 1.

Tabel 1. Taraf Perlakuan Roti Manis Substitusi Tepung Tempe dan Tepung Ubi Jalar Kuning

\begin{tabular}{cccc}
\hline \multirow{2}{*}{ Perlakuan } & \multicolumn{3}{c}{ Nama Bahan } \\
\cline { 2 - 4 } & Terigu & Tepung Tempe & Tepung Ubi Jalar Kuning \\
\hline R0 & $100 \%$ & $0 \%$ & $0 \%$
\end{tabular}




\begin{tabular}{llcc} 
R1 & $75 \%$ & $0 \%$ & $25 \%$ \\
R2 & $75 \%$ & $10 \%$ & $15 \%$ \\
R3 & $75 \%$ & $15 \%$ & $10 \%$ \\
R4 & $75 \%$ & $25 \%$ & $0 \%$ \\
\hline
\end{tabular}

Pembuatan roti manis dilakukan dengan pencampuran, pengadonan, pembentukan, dan pemanggangan. Tepung tempe yang digunakan adalah hasil penepungan tempe kedelai yang berasal dari Pasar Karang Ayu Semarang dan dibuat berdasarkan metode Sofiah, yaitu tempe dikukus selama 15 menit, diiris tipis, dikeringkan pada suhu $50^{\circ} \mathrm{C}$ selama 10 jam, digiling, dan diayak dengan tingkat kehalusan 80 mesh. $^{11}$ Sementara tepung ubi jalar kuning yang digunakan merupakan hasil penepungan ubi jalar kuning yang berasal dari Bandungan Semarang dan dibuat berdasarkan metode Suismono, yaitu ubi jalar yang telah dikupas dan dicuci kemudian dikukus selama 10 menit, diiris tipis, direndam dalam larutan sodium bisulfit $0,3 \%$ selama 30 menit, dikeringkan pada suhu $50^{\circ} \mathrm{C}$ selama 10 jam, digiling, dan diayak dengan tingkat kehalusan 80 mesh. ${ }^{12}$

Pada penelitian utama, data yang dikumpulkan dari variabel terikat adalah kadar protein, kadar $\beta$-karoten, dan mutu organoleptik roti manis. Kadar protein roti manis diukur dengan metode Kjeldahl dan kadar $\beta$-karoten diukur dengan metode spektrofotometri. ${ }^{13}$ Sementara itu, mutu organoleptik menggunakan uji hedonik dengan kriteria penilaian lima skala hedonik yaitu 1=sangat tidak suka; 2=tidak suka; 3=netral; 4=suka; dan 5=sangat suka. Penilaian mutu organoleptik dilakukan pada 20 orang panelis agak terlatih yaitu mahasiswa Program Studi Ilmu Gizi Fakultas Kedokteran Universitas Diponegoro.

Pengaruh substitusi tepung tempe dan tepung ubi jalar kuning terhadap kadar protein dan kadar $\beta$-karoten roti manis diuji menggunakan One Way Anova serta uji lanjut Tukey untuk mengetahui beda nyata kadar protein dan uji Duncan untuk mengetahui beda nyata kadar $\beta$ karoten antar perlakuan. Sementara itu, data mutu organoleptik menggunakan uji Friedman dan uji lanjut Wilcoxon.

\section{HASIL}

1. Kadar Protein dan $\beta$-karoten Roti Manis dengan Substitusi Tepung Tempe dan Tepung Ubi Jalar Kuning

Hasil analisis kadar protein dan $\beta$-karoten roti manis substitusi tepung tempe dan tepung ubi jalar kuning secara singkat disajikan pada Tabel 2.

Tabel 2. Rerata Kadar Protein dan $\beta$-karoten Roti Manis dengan Substitusi Tepung Tempe dan Tepung Ubi Jalar Kuning

\begin{tabular}{ccc}
\hline $\begin{array}{c}\text { Jenis } \\
\text { Perlakuan }\end{array}$ & $\begin{array}{c}\text { Rerata Kadar Protein } \\
(\% \text { berat kering })\end{array}$ & $\begin{array}{c}\text { Rerata Kadar } \beta \text {-karoten } \\
(\mathrm{mg} / 100 \mathrm{~g})\end{array}$ \\
\hline R0 & $11,34 \pm 0,27^{\mathrm{ab}}$ & $0,09 \pm 0,01^{\mathrm{b}}$ \\
R1 & $9,44 \pm 1,51^{\mathrm{b}}$ & $0,24 \pm 0,06^{\mathrm{a}}$ \\
R2 & $11,31 \pm 2,25^{\mathrm{ab}}$ & $0,21 \pm 0,03^{\mathrm{a}}$ \\
R3 & $12,41 \pm 1,56^{\mathrm{ab}}$ & $0,14 \pm 0,01^{\mathrm{b}}$ \\
R4 & $14,38 \pm 1,44^{\mathrm{a}}$ & $0,10 \pm 0,02^{\mathrm{b}}$ \\
\hline & $\mathbf{p}=\mathbf{0 . 0 3 2}^{*}$ & $\mathbf{p}=\mathbf{0 . 0 0 0}^{*}$
\end{tabular}

Angka yang diikuti huruf superscript berbeda menunjukkan beda nyata

Berdasarkan Tabel 2, kadar protein tertinggi terdapat pada roti manis dengan substitusi tepung tempe $25 \%$, yaitu $14,38 \%$ dan kadar protein terendah terdapat pada roti manis dengan substitusi tepung ubi jalar kuning $25 \%$, yaitu $9,44 \%$. Sementara itu, kadar $\beta$-karoten tertinggi terdapat pada roti manis dengan substitusi tepung ubi jalar kuning $25 \%$ yaitu $0,24 \mathrm{mg} / 100 \mathrm{~g}$, dan yang paling rendah terdapat pada roti manis $100 \%$ terigu, yaitu 0,09 $\mathrm{mg} / 100 \mathrm{~g}$.

2. Mutu Organoleptik Roti Manis dengan Substitusi Tepung Tempe dan Tepung Ubi Jalar Kuning

Hasil analisis mutu organoleptik warna, aroma, tekstur, dan rasa roti manis substitusi tepung tempe dan tepung ubi jalar kuning secara singkat disajikan pada Tabel 3 . 
Tabel.3 Rerata mutu organoleptik warna, aroma, tekstur, dan rasa roti manis substitusi tepung tempe dan tepung ubi jalar kuning

\begin{tabular}{|c|c|c|c|c|c|c|c|c|}
\hline \multirow{2}{*}{$\begin{array}{c}\text { Perlakua } \\
n\end{array}$} & \multicolumn{2}{|c|}{ Warna } & \multicolumn{2}{|c|}{ Aroma } & \multicolumn{2}{|c|}{ Tekstur } & \multicolumn{2}{|c|}{ Rasa } \\
\hline & Rerata & Ket & Rerata & Ket & Rerata & Ket & Rerata & Ket \\
\hline R0 & $\begin{array}{c}3,68 \pm \\
0,75^{\mathrm{a}}\end{array}$ & Suka & $\begin{array}{c}4,05 \pm \\
0,75^{\mathrm{a}}\end{array}$ & Suka & $\begin{array}{l}3,65 \pm \\
0,95^{\text {ac }}\end{array}$ & Suka & $\begin{array}{c}4,20 \pm \\
0,68^{\mathrm{a}}\end{array}$ & Suka \\
\hline R1 & $\begin{array}{c}3,88 \pm \\
0,87^{\mathrm{a}}\end{array}$ & Suka & $\begin{array}{c}3,57 \pm \\
0,81^{\mathrm{b}}\end{array}$ & Suka & $\begin{array}{l}3,25 \pm \\
0,84^{\mathrm{b}}\end{array}$ & $\begin{array}{c}\text { Netra } \\
1\end{array}$ & $\begin{array}{c}3,62 \pm \\
0,94^{\mathrm{b}}\end{array}$ & Suka \\
\hline R2 & $\begin{array}{c}3,82 \pm \\
0,70^{\mathrm{a}}\end{array}$ & Suka & $\begin{array}{l}3,60 \pm \\
0,87^{\mathrm{b}}\end{array}$ & Suka & $\begin{array}{l}3,65 \pm \\
0,92^{\mathrm{a}}\end{array}$ & Suka & $\begin{array}{c}3,35 \pm \\
0,97^{\mathrm{b}}\end{array}$ & Netral \\
\hline R3 & $\begin{array}{c}3,82 \pm \\
0,68^{\mathrm{a}}\end{array}$ & Suka & $\begin{array}{l}3,43 \pm \\
0,89^{b}\end{array}$ & $\begin{array}{c}\text { Netra } \\
1\end{array}$ & $\begin{array}{l}3,70 \pm \\
1,01^{\mathrm{a}}\end{array}$ & Suka & $\begin{array}{c}2,90 \pm \\
0,89^{c}\end{array}$ & Netral \\
\hline R4 & $\begin{array}{l}3,00 \pm \\
0,88^{\mathrm{b}}\end{array}$ & $\begin{array}{c}\text { Netra } \\
1\end{array}$ & $\begin{array}{c}2,97 \pm \\
0,88^{\mathrm{c}}\end{array}$ & $\begin{array}{c}\text { Netra } \\
1\end{array}$ & $\begin{array}{l}3,28 \pm \\
0,99^{\mathrm{bc}}\end{array}$ & $\begin{array}{c}\text { Netra } \\
1\end{array}$ & $\begin{array}{l}2,40 \pm \\
0,69^{\mathrm{d}}\end{array}$ & $\begin{array}{l}\text { Tidak } \\
\text { Suka }\end{array}$ \\
\hline & $\mathrm{p}=0.000^{*}$ & & $\mathrm{p}=0.000^{*}$ & & $\mathrm{p}=0.006^{*}$ & & $\mathrm{p}=0.000^{*}$ & \\
\hline
\end{tabular}

Angka yang diikuti huruf superscript berbeda menunjukkan beda nyata

Tabel 3. menunjukkan bahwa tingkat kesukaan warna roti manis tertinggi terdapat pada roti manis substitusi tepung ubi jalar kuning $25 \%$, yaitu 3,88 (suka), dan yang terendah terdapat pada roti manis substitusi tepung tempe $25 \%$, yaitu 3,00 (netral). Sementara itu, tingkat kesukaan aroma roti manis tertinggi terdapat pada roti manis $100 \%$ terigu, yaitu 4,05 (suka), dan yang terendah terdapat pada roti manis substitusi tepung tempe $25 \%$, yaitu 2,97 (netral).

Roti manis dengan substitusi tepung tempe $15 \%$ - tepung ubi jalar kuning $10 \%$ memiliki tingkat kesukaan tekstur tertinggi yaitu 3,70 (suka), sedangkan roti manis dengan substitusi tepung ubi jalar kuning 25\% memiliki tingkat kesukaan terendah yaitu 3,25 (netral). Sementara itu, roti manis $100 \%$ terigu memiliki tingkat kesukaan tertinggi yaitu 4,20 (suka), sedangkan roti manis dengan substitusi tepung tempe $25 \%$ memiliki tingkat kesukaan terendah yaitu 2,40 (tidak suka).

\section{PEMBAHASAN}

\section{Kadar Protein}

Substitusi tepung tempe dan tepung ubi jalar kuning tidak berpengaruh secara nyata terhadap kadar protein roti manis. Hal ini disebabkan kadar protein dalam masingmasing bahan yang berbeda. Kadar protein dalam terigu, tepung ubi jalar kuning, dan tepung tempe dalam penelitian ini berturutturut sebesar $11 \mathrm{~g}, 42,6 \mathrm{~g}$, dan 4,8 g. Kadar protein tepung ubi jalar kuning relatif rendah jika dibandingkan dengan terigu dan tepung tempe. Semakin banyak substitusi tepung ubi jalar kuning maka kadar protein roti manis cenderung menurun. Namun, kurangnya protein dalam tepung ubi jalar dapat tertutupi oleh protein tepung tempe, sehingga substitusi tepung ubi jalar kuning hingga 25\% tidak berpengaruh secara nyata terhadap penurunan kadar protein roti manis. ${ }^{14}$ Sementara itu, tepung tempe memiliki kadar protein tertinggi, tetapi substitusi tepung tempe hingga $25 \%$ pun tidak berpengaruh nyata terhadap peningkatan kadar protein roti manis. Hal ini diduga oleh jumlah substitusi tepung tempe yang relatif rendah.

Tempe merupakan olahan kacangkacangan yang tinggi kandungan lisin, tetapi rendah akan asam amino sulfur, sedangkan serealia (terigu) sebaliknya. ${ }^{5}$ Protein ubi jalar kuning juga rendah kandungan lisin dan asam amino sulfur. Substitusi tepung tempe pada pembuatan roti manis diharapkan dapat melengkapi kekurangan lisin pada terigu dan tepung ubi jalar. ${ }^{5,9,15}$ Penelitian Ahmed menunjukkan bahwa penambahan isolat protein kacang tolo pada terigu terbukti meningkatkan kandungan lisin pada semua campuran dan peningkatannya sebanding dengan jumlah isolat yang ditambahkan. ${ }^{16}$

Berdasarkan perhitungan dari data sekunder, ${ }^{17}$ kontribusi substitusi tepung tempe dan tepung ubi jalar kuning terhadap jumlah asam amino lisin dan asam amino sulfur disajikan pada Tabel 4. 
Tabel.4 Kontribusi Substitusi Tepung Tempe dan Tepung Ubi Jalar Kuning terhadap Jumlah Asam Amino Lisin, Metionin, dan Sistein

\begin{tabular}{lcrr}
\hline \multicolumn{1}{c}{ Perlakuan } & \multicolumn{3}{c}{ Asam Amino (mg/g N) } \\
\cline { 2 - 4 } & \multicolumn{1}{c}{ Lisin } & Metionin & \multicolumn{1}{c}{ Sistein } \\
\hline 100\% terigu & 130 & 108,12 & 131,87 \\
75\% terigu 25\% ubi jalar & 99,02 & 81,97 & 99,90 \\
75\% terigu 10\% tempe 15\% ubi jalar & 138,81 & 98,42 & 106,50 \\
75\% terigu 15\% tempe 10\% ubi jalar & 158,71 & 106,64 & 109,80 \\
75\% terigu 25\% tempe & 198,50 & 123,09 & 116,40 \\
\hline
\end{tabular}

Berdasarkan Tabel 4. dapat dilihat bahwa jumlah lisin cenderung meningkat dengan semakin banyaknya substitusi tepung tempe, sedangkan jumlah asam amino sulfur sebaliknya. Meskipun demikian, jumlah asam amino sulfur kombinasi ketiga tepung tersebut masih lebih tinggi apabila dibandingkan dengan jumlah asam amino sulfur yang dihasilkan dari tepung tempe sendiri. ${ }^{17}$

\section{Kadar $\beta$-karoten}

Roti manis substitusi tepung ubi jalar kuning 25\% dan roti manis substitusi tepung tempe 10\%-tepung ubi jalar kuning $15 \%$ memiliki kadar $\beta$-karoten yang berbeda nyata dengan roti manis $100 \%$ terigu. Penelitian Idolo menunjukkan bahwa substitusi tepung ubi jalar kuning 20\% meningkatkan kadar $\beta$ karoten roti manis $12,1 \%$, sedangkan substitusi sebesar $25 \%$ meningkatkan kadar $\beta$ karoten $34,5 \%$ dari kandungan $\beta$-karoten roti manis tanpa substitusi. Semakin banyak substitusi tepung ubi jalar kuning yang ditambahkan, maka kadar $\beta$-karoten roti manis cenderung meningkat secara nyata. ${ }^{18}$

Ubi jalar kuning mengandung $\beta$-karoten yang cukup tinggi. Sekitar $89 \%$ total karoten pada ubi jalar kuning adalah $\beta$-karoten yang didominasi oleh bentuk trans- $\beta$-karoten sebesar $96,7 \%$. Namun demikian, kandungan $\beta$-karoten tersebut dapat berkurang dan mengalami kerusakan karena proses pengolahan. Adanya struktur ikatan rangkap pada $\beta$-karoten menyebabkan $\beta$-karoten mudah teroksidasi ketika terkena udara $\left(\mathrm{O}_{2}\right)$. Proses oksidasi pun akan berlangsung lebih cepat dengan adanya cahaya, katalis logam, dan proses pemanasan pada suhu tinggi. Hal tersebut dapat mengakibatkan berubahnya struktur trans- $\beta$-karoten menjadi cis- $\beta$ karoten, dimana bentuk cis- $\beta$-karoten memiliki aktivitas provitamin A yang lebih rendah. $^{12}$
Penelitian tentang stabilitas $\beta$-karoten selama proses produksi tepung ubi jalar klon $\mathrm{BB}$ menunjukkan adanya penurunan kadar $\beta$ karoten sebesar $38-40 \%$ dan kerusakan strukturnya karena proses pengeringan. Namun demikian, apapun metode pengolahan yang dilakukan, kadar $\beta$-karoten akan mengalami penurunan, terutama dengan waktu proses yang lebih lama, adanya pemotongan, serta penggilingan. Adanya proses pemotongan dan penggilingan umbi menyebabkan bertambahnya luas permukaan bahan, sehingga peluang kontak dengan udara $\left(\mathrm{O}_{2}\right)$ juga lebih besar. ${ }^{12}$

Kandungan $\beta$-karoten dalam tepung ubi jalar kuning juga dapat berkurang karena adanya proses pengolahan produk aplikasinya, seperti pada pembuatan roti. Penelitian Lisia tentang aplikasi tepung ubi jalar kuning dalam pembuatan roti menunjukkan adanya penurunan $\beta$-karoten sebesar $68,5 \%$ selama pemanggangan dalam oven pada suhu $\pm 160^{\circ} \mathrm{C}$ selama 15 menit. Jumlah penurunan akan semakin besar seiring dengan bertambahnya suhu dan waktu pemanggangan. ${ }^{19}$

Namun demikian, kadar $\beta$-karoten dalam penelitian ini masih dapat dipertahankan. Hal ini dapat disebabkan oleh penggunaan sodium bisulfit pada pembuatan tepung ubi jalar kuning. Pada penelitian ini, pembuatan tepung dilakukan dengan perendaman irisan ubi jalar dalam larutan sodium bisulfit $0,3 \%$ selama 30 menit sebelum dikeringkan. Hal tersebut dilakukan untuk meminimalkan penurunan kadar $\beta$ karoten, karena sodium bisulfit berperan dalam melindungi $\beta$-karoten dari oksidasi. Penelitian Christina menunjukkan bahwa tepung ubi jalar yang dihasilkan dari perlakuan perendaman larutan sodium bisulfit $0,3 \%$ memiliki kadar $\beta$-karoten tertinggi dibandingkan dengan tepung ubi jalar dengan 
perendaman dalam asam askorbat, gum arab, dan maltodekstrin. ${ }^{12}$

\section{Mutu Organoleptik}

\section{a. Warna}

Substitusi tepung tempe dan tepung ubi jalar kuning menghasilkan roti manis berwarna kuning cerah hingga kuning kecokelatan. Dibandingkan perlakuan lainnya, hanya tingkat kesukaan warna roti manis substitusi tepung tempe $25 \%$ yang berbeda nyata dengan roti manis $100 \%$ terigu. Hal tersebut karena roti manis substitusi tepung tempe $25 \%$ memiliki warna cokelat yang lebih pekat. Warna roti manis yang dihasilkan berasal dari tepung tempe dan tepung ubi jalar kuning yang digunakan. Tepung tempe memiliki warna cokelat, sedangkan tepung ubi jalar kuning memiliki warna jingga muda. Pada penelitian ini, semakin banyak substitusi tepung tempe yang ditambahkan, maka warna roti manis semakin cokelat. Hal ini terlihat pada roti manis substitusi tepung tempe $25 \%$ yang memiliki warna paling cokelat.

Di samping karena penggunaan tepung tempe, warna kecokelatan pada roti juga dihasilkan oleh reaksi Maillard. Reaksi Maillard merupakan reaksi browning non enzimatis yang terjadi antara gula pereduksi dengan asam amino yang menghasilkan warna kecokelatan pada bahan makanan ketika mengalami proses pemanasan. Cornell menyebutkan reaksi Maillard pada produk bakery dapat terjadi karena adanya proses pemanggangan pada suhu di atas $115^{\circ} \mathrm{C} .^{20}$ Di samping itu, semakin banyak substitusi tepung tempe yang ditambahkan, warna roti manis akan semakin gelap. Hal ini dikarenakan kandungan asam amino lisin yang tinggi pada tepung tempe turut mempengaruhi warna roti yang dihasilkan. Lisin mengandung dua gugus amin sehingga lebih reaktif terhadap gula pereduksi dan menghasilkan warna kecokelatan yang lebih pekat, sedangkan asam amino yang mengandung sulfur seperti metionin dan sistein sebaliknya. ${ }^{11,21}$

b. Aroma

Aroma roti manis substitusi tepung tempe dan tepung ubi jalar kuning pada penelitian ini memiliki tingkat kesukaan suka hingga netral. Tingkat kesukaan aroma roti manis seluruh perlakuan substitusi tepung tempe dan tepung ubi jalar kuning berbeda nyata dengan roti manis $100 \%$ terigu. Roti manis substitusi tepung tempe $10 \%$-tepung ubi jalar kuning $15 \%$ dan roti manis substitusi tepung ubi jalar kuning 25\% memiliki aroma harum khas ubi jalar kuning. Sementara itu, roti manis substitusi tepung tempe $15 \%$-tepung ubi jalar kuning $10 \%$ dan roti manis substitusi tepung tempe $25 \%$ memiliki aroma langu yang kuat.

Aroma langu pada roti manis dapat disebabkan oleh tepung tempe yang digunakan. Aroma langu pada tepung tempe disebabkan oleh aktivitas enzim lipoksigenase yang secara alami terdapat dalam kedelai. Enzim lipoksigenase dapat menghidrolisis asam lemak tak jenuh ganda dan menghasilkan senyawa-senyawa volatil penyebab aroma langu, khususnya etil fenil keton. Pada penelitian ini, sebelum dilakukan proses pengeringan, tempe yang digunakan di-blanching terlebih dahulu pada suhu $100^{\circ} \mathrm{C}$ selama 15 menit. Hal ini dilakukan untuk menginaktivasi enzim lipoksigenase yang terdapat dalam tempe. Cowan menyebutkan bahwa proses steam blanching dengan pengukusan pada suhu $70-100^{\circ} \mathrm{C}$ selama 10 atau 40 menit pada pembuatan tepung tempe telah mampu menginaktivasi enzim lipoksigenase dan memperbaiki aroma tepung yang dihasilkan. ${ }^{11}$

\section{c. Tekstur}

Tekstur roti manis substitusi tepung tempe dan tepung ubi jalar kuning pada penelitian ini memiliki tingkat kesukaan suka hingga netral. Dibandingkan perlakuan lainnya, hanya tingkat kesukaan tekstur roti manis substitusi tepung ubi jalar kuning 25\% yang berbeda nyata dengan roti manis tanpa substitusi. Roti manis substitusi tepung ubi jalar kuning $25 \%$ memiliki tingkat kesukaan tekstur terendah, dengan tekstur padat, agak kasar, dan mudah hancur ketika dikunyah.

Perbedaan tekstur roti manis yang dihasilkan dalam penelitian ini dapat disebabkan oleh kandungan gluten dalam tepung yang digunakan. Gluten merupakan massa adonan yang tak larut air, liat, elastis, dan dapat mengembang, yang 
terbentuk dari fraksi protein gliadin dan glutenin yang bereaksi dengan air. Sifat gluten yang elastis membuat adonan roti dapat menahan gas $\mathrm{CO}_{2}$ hasil fermentasi ragi, sehingga adonan dapat mengembang dan meningkatkan volume roti. Peningkatan volume tersebut, memungkinkan roti memiliki struktur berongga yang halus, seragam, dan tekstur yang lembut. ${ }^{22}$ Tepung ubi jalar kuning memiliki kandungan gluten yang sangat rendah, sehingga semakin banyak tepung ubi jalar kuning yang ditambahkan, maka kelembutan tekstur roti manis akan berkurang.

Di samping kandungan gluten, tekstur roti manis juga dipengaruhi oleh rasio amilosa dan amilopektin pada tepung ubi jalar kuning. Pati pada umbi-umbian seperti ubi jalar mengandung kadar amilosa yang tergolong tinggi, yaitu 30$40 \% .^{15,23}$ Adanya kandungan amilosa yang tinggi menimbulkan tekstur padat dan kasar pada makanan. ${ }^{22,23}$

\section{d. Rasa}

Pada penelitian ini, rasa roti manis substitusi tepung tempe dan tepung ubi jalar kuning memiliki tingkat kesukaan suka hingga tidak suka. Tingkat kesukaan panelis terhadap rasa roti manis seluruh perlakuan substitusi berbeda nyata dengan roti tanpa substitusi, dan cenderung menurun dengan semakin banyaknya tepung tempe yang ditambahkan.

Rasa roti manis yang dihasilkan dalam penelitian ini dipengaruhi oleh komposisi tepung yang digunakan. Roti manis substitusi tepung tempe $25 \%$ memiliki tingkat kesukaan terendah, yaitu 2,40 (tidak suka). Hal ini dikarenakan adanya after taste berupa rasa pahit pada roti. After taste pahit dapat disebabkan oleh hidrolisis asam-asam amino yang terjadi pada reaksi Maillard, baik saat proses pembuatan tepung tempe maupun saat pemanggangan roti. Johnson dan Peterson menyebutkan bahwa terdapat asam-asam amino yang menimbulkan rasa pahit seperti lisin, arginin, prolin, fenilalanin, dan valin. Asam amino lisin merupakan asam amino yang memiliki rasa paling pahit dibandingkan asam amino penyebab rasa pahit lainnya. ${ }^{11,21,24}$

\section{Rekomendasi Roti Manis dan Kontribusi terhadap Kecukupan Gizi}

Roti manis yang direkomendasikan adalah roti manis substitusi tepung tempe $10 \%$-tepung ubi jalar kuning $15 \%$. Berdasarkan perhitungan kadar protein dan $\beta$ karoten, roti manis tersebut memiliki kontribusi yang paling optimal terhadap kecukupan protein dan vitamin A anak berdasarkan AKG dibandingkan dengan roti manis perlakuan lainnya, serta memiliki mutu organoleptik yang dapat diterima panelis. Konsumsi $100 \mathrm{~g}$ roti manis tersebut dapat menyumbang $25,15 \%$ kecukupan protein dan 9\% kecukupan vitamin A anak usia 4-8 tahun atau menyumbang $22,62 \%$ kecukupan protein dan 6\% kecukupan vitamin A anak usia 9-13 tahun.

\section{SIMPULAN DAN SARAN \\ Simpulan}

1. Kadar protein roti manis cenderung meningkat dengan semakin banyaknya substitusi tepung tempe dan menurun dengan semakin banyaknya substitusi tepung ubi jalar kuning.

2. Kadar $\beta$-karoten roti manis cenderung meningkat dengan semakin banyaknya substitusi tepung ubi jalar kuning dan menurun dengan semakin banyaknya substitusi tepung tempe.

3. Substitusi tepung tempe dan tepung ubi jalar kuning berpengaruh secara nyata terhadap mutu organoleptik warna, aroma, tekstur, dan rasa roti manis.

\section{Saran}

1. Diperlukan proses pengolahan tambahan pada saat pembuatan tepung tempe untuk mengurangi aroma langu akibat enzim lipoksigenase, misalnya dengan pengukusan tempe pada suhu $100^{\circ} \mathrm{C}$ selama 40 menit.

2. Penambahan filling (bahan pengisi) seperti cokelat dan selai ke dalam roti manis dapat dilakukan untuk menutupi after taste pahit.

3. Roti manis yang direkomendasikan adalah roti manis substitusi tepung tempe $10 \%$ tepung ubi jalar kuning $15 \%$.

\section{DAFTAR PUSTAKA}

1. Muller O, Krawinkel M. Malnutrition and health in developing countries. Canadian Medical Association Journal. 2005; 173(3): 279-286.

2. Kementrian Kesehatan Republik Indonesia. Laporan Hasil Riset Kesehatan Dasar. 2010. 
3. Arisman. Gizi dalam daur kehidupan. Jakarta: Penerbit Buku Kedokteran EGC, 2007; p.92-93.

4. Singh V, West KP. Vitamin A deficiency among school-aged children in Southeastern Asia. Eur J Clin Nutr. 2004; 58(10): 1342-1349.

5. Gallagher ML. The nutrients and their metabolism. In: Mahan LK, Escott-Stump S. Krause's food and nutrition theraphy. $12^{\text {th }}$ ed. Canada: Saunders Elsevier, 2008; p.64-69, 7173.

6. Ikekpeazu EJ, Neboh EE, Maduka IC, Ezedigbo AN, Odetunde T. Serum vitamin A levels in children with protein energy malnutrition. Curr Pediatr Res. 2010; 14(1): 9-13.

7. Ani Kurniawan. Policies in alleviating micronutrient deficiencies: Indonesia's experience. Asia Pacific J Clin Nutr. 2002;11(3) : S360-S370.

8. Mary Astuti, Andreanyta Meliala. Tempe: A nutritious and healthy food from Indonesia. Asia Pacific J. Clin Nutr. 2000; 9(4): 322-325.

9. Indrie Ambarsari, Abdul Choliq. Rekomendasi dalam penetapan standar mutu tepung ubi jalar. Jurnal Standardisasi. 2009; 11(3): 212-219.

10. Handewi Purwati Saliem, Reni Kustiari. Situation and trends of wheat flour consumption in Indonesia: Analysis of susenas food consumption data (1996-2008). Departemen Pertanian Indonesia. 2010.

11. Paula Kartika Dewi. Pengaruh lama fermentasi dan suhu pengeringan terhadap jumlah asam amino lisin dan karakter fisiko kimia tepung tempe. [skripsi]. Semarang: Fakultas Pertanian Universitas Katolik Soegijapranata Semarang. 2006.

12. Christina Mumpuni Erawati. Kendali stabilitas betakaroten selama proses produksi tepung ubi jalar (Ipomoea batatas L.). [tesis]. Bogor: Sekolah Pascasarjana Institut Pertanian Bogor. 2006.

13. Abdul Rohman Sumantri. Analisis makanan. Jogjakarta: Gajah Mada University Press, 2007; p.5, 122 .

14. Lyimo ME, Gimbi DM, Shayo NB. Nutritional evaluation of composite flour based on root and tuber crops and sensory acceptability of the developed products. In: Proceedings of the $13^{\text {th }}$ ISTRC Symposium. Arusha: Department of Food Science and Technology, Tanzania University of Agriculture, 2007; p.514-520.

15. Padmaja G. Uses and nutritional data of sweet potato. In: George T, editor. The sweet potato. Berlin: Springer Science, 2009; p.190-199,212.

16. Ahmed SB, Abu-Tarboush HM, Al-Mana HA. Amino acid composition and rheological properties of doughs of wheat flour and cowpea protein isolate modified chemically and enzymatically. J. Saudi Soc. For Food and Nutrition 2007; 2 (2).
17. Deddy Muchtadi.Teknik evaluasi nilai gizi protein. Bandung: Alfabeta, 2010; p.72-145.

18. Idolo I. Sensory and nutritional quality of madiga produced from composite flour of wheat and sweet potato. Pak J Nutr. 2011; 10(11): 10041007.

19. Lisia Yusianti, Purwiyatno Hariyadi. Kajian formulasi dan proses pemanggangan roti kaya karotenoida dengan substitusi tepung ubi jalar dan minyak sawit. [skripsi]. Bogor: Fakultas Teknologi Pertanian Institut Pertanian Bogor. 2001.

20. Cauvain SP. Bread making improving quality. $1^{\text {st }}$ ed. Cambridge: Woodhead Publishing Limited, 2003; p.62.

21. Maaruf AG, Linforth RS, Taylor AJ. Interaction of temperature/time and humidity on the generation of wheat bread flavor. University Kebangsaan Malaysia and University of Nottingham Research. 2004.

22. Cauvain SP, Young L. Baking problem solved. $1^{\text {st }}$ ed. Cambridge: Woodhead Publishing Limited, 2001; p.18-19.

23. Tien Muchtadi, Fitriyono Ayustaningwarno. Ilmu pengetahuan bahan pangan. Bandung: Alfabeta, 2010; p.218-219.

24. Kam Huey Wong. Sensory aroma of maillard reaction of individual and combinations of amino acids with glucose in acidic conditions. International Journal of Food Science and Technology. 2008; 43: 1512-1519. 